\title{
Work conditions and their repercussions on the quality of life of rural workers*
}

\author{
As condições de trabalho e suas repercussões na qualidade de vida de trabalhadores rurais \\ Las condiciones de trabajo y su repercusión en la calidad de vida de los trabajadores rurales
}

How to cite this article:

Oliveira JCAX, Corrêa ACP, Cezar-Vaz MR, Marcon SR, Rosa ITM, Dalprá LAS. Work conditions and their repercussions on the quality of life of rural workers. Rev Esc Enferm USP. 2021;55:e20200408. DOI: https://doi.org/10.1590/1980-220X-REEUSP-2020-0408

\section{Jeane Cristina Anschau Xavier de Oliveira ${ }^{1}$

(D) Áurea Christina de Paula Corrêa ${ }^{2}$
(i) Marta Regina Cezar-Vaz ${ }^{3}$
(D) Samira Reschetti Marcon ${ }^{2}$
(iD) Isabele Torquato Mozer Rosa ${ }^{2}$
(D) Luanna Arruda e Silva Dalprá ${ }^{2}$

* Extracted from the thesis: "A qualidade de vida de homens trabalhadores rurais inseridos no contexto da soja”, Universidade Federal de Mato Grosso, 2020.

${ }^{1}$ Universidade Federal de Mato Grosso, Instituto de Ciências da Saúde, Campus Sinop, Sinop, MT, Brazil.

${ }^{2}$ Universidade Federal de Mato Grosso, Faculdade de Enfermagem, Cuiabá, MT, Brazil.

${ }^{3}$ Universidade Federal do Rio Grande, Escola de Enfermagem, Rio Grande, RS, Brazil.

\begin{abstract}
Objective: To assess the context of work and analyze their repercussions on the quality of life of rural workers in soybean agribusiness. Method: Cross-sectional study, with an intentional sample of rural workers, conducted between the months of October and December 2019, with the application of the instruments World Health Organization Quality Life-bref and Scales of Assessment of Context and Human Cost of Work. The data were analyzed through bivariate and multivariate descriptive statistics. Results: The participants amounted to 299 rural workers. The scores of Work Conditions and Socioprofessional Relations were satisfactory and Organization of Work was critical. The scores of Physical and Cognitive costs were considered critical and of the Affective Cost was satisfactory. The Socioprofessional Relations have negatively impacted the overall quality of life and the Physical and Psychological, the Social Relations and the Environmental Domains, whereas Cognitive Cost positively impacted the Physical and the Environmental Domain and the Affective Cost positively impacted the Social Relations Domain. Conclusion: Although the Work Context and Human Cost indicated adverse conditions, only the Socioprofessional Relations exerted negative influences on the quality of life of rural workers.
\end{abstract}

\section{DESCRIPTORS}

RuralWorkers; Working Conditions; Quality of Life; Occupational Health; Occupational Health Nursing. 


\section{INTRODUCTION}

Studies on Quality of Life (QL) have been attracting researchers' attention to several aspects of population health worldwide; however, when it comes to the rural population, scientific literature, mainly in Brazil, presents significant gaps on the inter-relation between $\mathrm{QL}$ and life conditions, health, and, mainly, with the working contexts of male rural workers.

The choice of investigating the QL of rural workers was due to the verification that Agribusiness is one of the most relevant economic sectors in Brazil, with a predominantly male population ${ }^{(1)}$.

Even during the COVID-19 pandemic, when the income of several economic sectors had decreased due to the sanitary restrictions, the Brazilian 2019/20 grain crop had a $4.8 \%$ increase, amounting to 253.7 million tons, which makes it the biggest crop in the history of grain production in Brazil, particularly for soybeans, corn, and $\operatorname{cotton}^{(2)}$. The soybean crop plantation was started in September 2019 and harvest was finished in April 2020, during the COVID-19 pandemic; i.e., the production could have been bigger, with even more positive economic impacts, had the pandemic not occurred.

So far, there is no consensus on the concept of QL, given that this may differ among people, places, and even throughout life; there is however an agreement that it has several determinant factors. Therefore, this study employed the concept of QL proposed by the World Health Organization (WHO), which defines it as a set of perceptions of individuals from their position in life, their cultural context, and system of values, considering their goals, expectations, standards, and preoccupations ${ }^{(3)}$.

The assessment of QL of a population includes both subjective aspects and individual and socioenvironmental factors around them in each sociocultural context, as well as objective aspects related to life, health, and work conditions assessment ${ }^{(4)}$.

To understand how work influences the QL of individuals, Psychodynamics of Work was employed as conceived by Christophe Dejours ${ }^{(5)}$, who developed a theoretical and methodological set whose object of study are the dynamic relations between work organization and the subjectivation processes shown in experiences of pleasure and suffering at work, as well as in strategies of action to mediate the contradictions of work organization, in social diseases, in health, and in sickness due to the work process ${ }^{(6)}$.

The conceptual bases of Psychodynamics of Work are elaborated through the analysis of dynamics inherent to the Work Context, based on the effect of visible and invisible, objective and subjective, psychic, social, political and economic forces, which may or may not damage this context, converting it into a place of health or sickness ${ }^{(6)}$.

From these conceptions, Psychodynamic of Work proposes a work organization which accounts for the collective dimension of work to provide "pleasure in the work environment and, to this end, the organization must offer conditions for workers to develop three important actions: mobilization of practical intelligence, public space of discussion, and cooperation" ${ }^{\prime 7}$.

Thus, the Context of Work is understood to possibly exert direct influences on physical and/or psychic health and, consequently, on the $\mathrm{QL}$ of workers ${ }^{(8-9)}$. Nevertheless, studies relating Context of Work and QL among rural workers are scarce, particularly when it comes to men, since rural work is composed of around $80 \%$ of male paid workers ${ }^{(1)}$.

Even so, a systematic review conducted in Brazilian and international databases with the objective of analyzing the scientific production on QL of rural workers from 1996 to 2012 has not indicated a particularly expressive production, and the only three international studies found rather focused on compromised QV due to musculoskeletal disorders ${ }^{(10)}$. No study relating the issues of subjectivity and the organization of work were found for the analysis of Context of Work.

Understanding the inter-relation between $\mathrm{QL}$ and rural work may contribute to the Nursing and Public Health areas, mainly concerning care of rural populations, by broadening theoretical, practical, and methodological knowledge on the work environment and the rural worker ${ }^{(11)}$. The population and health professionals, particularly Nurses, must be involved in the discussion around healthcare aimed at promoting quality of QL among rural workers, with an emphasis on the implementation of health education, conduction of studies, funding, and organization of services in the rural context ${ }^{(12)}$, with a special focus on the context of work of this population.

Given the above, this research poses the following question: how do the Work Conditions experienced by male rural workers inserted into the context of soybean production impact their quality of life?

Considering the need of understanding and reflecting on the processes of work and their consequences, this study had the objective of assessing the Context of Work and analyzing its repercussions on the quality of life of rural workers in soybean agribusiness.

\section{METHOD}

\section{Design of Study}

Cross-sectional, quantitative study.

\section{Population}

Study conducted in the rural area of the municipality of Sinop, in the state of Mato Grosso, Brazil, with male rural workers in the context of soybean production. Sinop is located in the center-north region of the state of Mato Grosso and - alongside the municipalities of Sorriso and Lucas do Rio Verde - is part of the economic center of this macroregion, due to the intense production of cultures such as soybeans, corn, and cotton and livestock, particularly the production of poultry and pigs. The municipality was also classified by the Brazilian Ministry of Tourism as the Portal of Agribusiness.

Its estimated population in 2017 was 956 rural male workers employed in soybean production ${ }^{(13)}$. Due to the difficulty of access to farms and warehouses that produce 
soybeans, a non-probabilistic convenience sample was obtained; it comprised workers of the establishment who allowed researcher access. To establish the sample, sample size, a $50 \%$ proportion for unknown prevalence of the outcome, $95 \%$ confidence $(z \alpha / 2=1.96)$, and $5 \%$ sample error were considered. The obtained sample was approximately 277 added to $15 \%$ for possible loss to follow-up, amounting to 318 male rural workers.

Authorization for this study was requested to 25 establishments, 16 of which were farms and 9 of which were warehouses/silos; however, only 6 farms and 6 warehouses/silos have authorized research. A total of 315 rural workers have been interviewed; however, due to incompletely filled instruments, 16 participants have been excluded, leading to a final sample of 299 male rural workers.

\section{Selection Criteria}

Male workers aged over 18 working in activities related to soybean production were included. Workers who were in tillage or in some labor activities at the moment of collection were excluded, and so were workers who were on vacation or medical leave. Workers who did not answer all the study instruments were considered lost to follow-up.

\section{Data Collection}

Data collection lasted from October to December 2019, during soybean plantation in the 2019/20 crop. The Brazilian version of World Health Organization Quality Life-bref (WHOQOL-bref), developed by the $\mathrm{WHO}^{(14)}$ was applied to assess QL. This scale is composed of two general questions (on QL perception and health satisfaction) and 24 questions related to the Physical, Psychological, Social, and Environmental Domains, totaling 26 questions. The results which were obtained with the application of the WHOQOL-Bref scale have presented evidence of reliability, identified through Cronbach's alpha coefficient $(\alpha=0.85)$. The information obtained from this scale comprised the dependent variables.

For analyzing work-related conditions two other scales were used: Work Context Assessment Scale (Escala de Avaliação do Contexto de Trabalbo - EACT) and the Human Cost of Labor Assessment Scale (Escala de Avaliação do Custo Humano do Trabalho - EACHT). Both integrate the Work and Illness Risks Inventory (Inventário de Trabalho e Riscos de Adoecimento - ITRA) ${ }^{(6)}$, whose theoretical framework is based on Dejours' theory of Psychodynamics of Work ${ }^{(5)}$. This inventory is composed of four interdependent scales aimed at assessing the four dimensions of inter-relation between work and risks of illness. To conduct this research, the EACT and EACHT scales were used due to their deep picture of the inter-relation work-health-illness in rural workers. The EACT scale is composed of three factors: 1. Work Organization, encompassing 11 items on task division, regulation, control, and work rhythm; 2 . Work Conditions, composed of 10 items which aim to express the quality of the available physical environment, work post, equipment, and material for work performance; and
3. Socioprofissional Relations, composed of 10 items which reflect the procedures of work management, communication, and professional interaction ${ }^{(6)}$.

The EACHT scale comprises three factors: 1 . Physical Cost, encompassing 10 questions on the cost of physiological and biomechanical energy demanded from the rural worker in performing their work activities within their work context; 2. Cognitive Cost, composed of 10 items exploring the intellectual effort for learning, problem-solving, and decision-making regarding their task; and 3. Affective Cost, comprising 12 items which deal with the emotional involvement to reveal affective and sentimental behavior and the workers' moods ${ }^{(6)}$.

These are Likert-type scales and have a variance of $38.46 \%$ and $44.46 \%$, respectively, both with factor loading over 0.30 and a Cronbach's alpha of 0.75 and 0.84 , respectively ${ }^{(6)}$. In both scales, the cut-off point for factor classification is established in three different levels, considering the standard deviation in relation to the mean point. Mean values over 3.7 are assessed as severe, indicating that the work context and the human cost of work severely facilitate the illnesses of workers. Mean values from 2.3 to 3.69 represent a critical assessment, indicating that the context of work and the human cost of work moderately favor the illnesses of workers. Mean values under 2.29 represent a satisfactory assessment, indicating that the context of work and the human cost of work favor worker health ${ }^{(6)}$.

The scales were previously validated for different professions (auditors, nurses, policemen, bank clerks); however, their structures had not yet been tested in rural workers. For this reason, new analyses have been performed to confirm the structure of factors in this professional group. The results confirm the factor structure of the original scales in the sample of rural workers. The EACT scale presented a factor loading of 0.69 , Cronbach's alpha of 0.82 and explained $55 \%$ of this measure's variance. Regarding the EACHT scale, the Physical Cost factor has presented a factor loading of 0.80; the Cognitive Cost factor had a factor loading of 0.77 , whereas the Affective Cost had a factor loading of 0.66. The EACTH scale has presented a Cronbach's alpha of 0.82 and explained $45 \%$ of the measure's variance. The mean scores of the EACT and EACHT scales comprised the independent variables of this study.

\section{Data Treatment and Analysis}

The data were typed and organized in the Microsoft Excel $^{\oplus}$ software and data analysis was performed with the Statistical Package for the Social Sciences (SPSS) version 20 for bivariate analysis. The $\mathrm{R}$ software, with the GAMLSS package $^{(15)}$, was employed for multivariate analysis. Descriptive analyses of relative and absolute frequency have been performed, as well as measures of central tendency (mean and median) and dispersion (standard deviation). To test the normality of the distributions of dependent variables, Shapiro Wilk test was used, showing that the data were non-parametric. 
For comparison analyses, Mann-Whitney (dichotomic variables) and Kruskal-Wallis (variables with three or more categories) tests were employed; the latter was followed by Dunn's post-hoc test. A 5\% significance level ( $\mathrm{p}<0.05)$ was adopted. To control for confounding, only the independent variables with $\mathrm{p}<0.10$ in the bivariate analysis have been included in the generalized additive models for location, scale, and shape (GAMLSS), a method to model the mean, variance, asymmetry, and kurtosis into a single model. In this model, the negative sign regarding the estimate coefficient indicates a reduction of scores for that domain and, oppositely, the positive sign corresponds to an increase in scores, when the other variables are constant in the model. To choose the best distribution to model the data, the Akaike Information Criterion (AIC) was used. The adopted significance level was $5 \%(\mathrm{p}<0.05)$.

\section{Ethical Aspects}

This study was approved by the Health Ethics Committee, Sinop Campus, on Opinion n. 3.085.698 in 2018 and was performed in accordance with the Norms and Directives Regulating Research Involving Human Beings, according to the Resolution of the Brazilian National Health Council, n. 466/2012. All participants signed the Informed Consent Form after its content, risks, and benefits of research participation were explained.

\section{RESULTS}

This study's participants were 299 male rural workers employed in soybean production, with a mean age of 34 years. They were mostly brown (45.8\%), single (35\%), with Secondary Education (52.2\%), Catholic (60\%), with a mean of 1.41 children, born in the state of Maranhão (29\%), who slept at work (58\%) and used their own vehicles (66\%), were hired employees (98\%), not unionized (66\%), performing the function of agricultural machinery operator (29\%), with a mean monthly income of 2,141.92 Brazilian reais and real income of 3,195.46 reais in crop season, with a mean workload of 45 hours per week outside the crop season and 73 hours per week in the crop season, with a mean of 10 years of rural work and 7 years working with soybeans.

In the descriptive analysis presented in Table 1, a satisfactory classification regarding the Work Conditions $(1.81 \pm 0.67)$ and Socioprofessional Relations $(1.86 \pm 0.74)$. Regarding the factor Work Organization, a critical assessment was observed among workers $(2.53 \pm 0.65)$. The factor Physical Cost presented a critical classification $(2.94 \pm 0.87)$, as well as the factor Cognitive Cost $(3.32 \pm 0.89)$. For the factor Affective Cost, a satisfactory assessment was identified among workers $(2.00 \pm 0.80)$.

From the comparison of scores of the domains of QL and of the Work Context, described in Table 2, there was a statistically significant difference in the Physical Domain for the factor Socioprofessional Relations ( $p=0.003$ ); in Dunn's post-hoc analysis, differences between the categories severe $\neq$ satisfactory and critical $\neq$ satisfactory were found.

In the Psychological Domain, there was a statistically significant difference for the factor Socioprofessional Relations ( $p=0.028$ ); however, no significant difference was verified in Dunn's post-hoc analysis. In the Social Relations domain, there was a statistically significant difference for the factor Socioprofessional Relations ( $p$ 0.001) and, in Dunn's post-hoc analysis, a difference was observed between the categories critical $\neq$ satisfactory.

In the Environmental Domain, there was a statistically significant difference for the factor Work Conditions $(p=0.008)$ and, in Dunn's post-hoc analysis, a difference was observed between the categories critical $\neq$ satisfactory. Likewise, there was a statistically significant difference for the Socioprofessional Relations factor $(p>0.001)$ and, in Dunn's post-hoc analysis, there was a difference in the categories critical $\neq$ satisfactory, and also between the categories severe $\neq$ satisfactory.

Upon analysis of the factor referring to the Context and Human Cost of Work on the overall QL and the domains (Physical, Psychological, Social Relations, Environmental), the Socioprofessional Relations were verified to negatively impact all the domains and the overall $\mathrm{QL}$ of these workers. However, the Cognitive Cost factor was identified to

Table 1 - Descriptive analysis of Work Context Assessment Scale and Human Cost of Work Assessment Scale in rural workers - Sinop, MT, Brazil, 2019.

\begin{tabular}{|c|c|c|c|c|c|c|}
\hline \multicolumn{7}{|c|}{ Assessment of work context } \\
\hline & Median & Mean $(\overline{\mathbf{x}})$ & Minimum & Maximum & Standard deviation & Classification \\
\hline Work conditions & 2.0 & 1.81 & 1.0 & 4.0 & 0.67 & Satisfactory \\
\hline Work organization & 2.5 & 2.53 & 1.0 & 4.6 & 0.65 & Critical \\
\hline Socioprofessional relations & 2.0 & 1.86 & 1.0 & 5.0 & 0.74 & Satisfactory \\
\hline \multicolumn{7}{|c|}{ Human cost of work assessment } \\
\hline & Median & Mean $(\overline{\mathbf{x}})$ & Minimum & Maximum & Standard deviation & Classification \\
\hline Physical cost & 3.0 & 2.94 & 1.0 & 5.0 & 0.87 & Critical \\
\hline Cognitive cost & 3.0 & 3.32 & 1.0 & 5.0 & 0.89 & Critical \\
\hline Affective cost & 1.8 & 2.00 & 1.0 & 4.3 & 0.80 & Satisfactory \\
\hline
\end{tabular}

Note: $(n=299)$. 
Table 2 - Comparison between the scores of the Brazilian version of World Health Organization Quality Life-bref (WHOQOL-Bref) and the scores of Work Context Assessment Scale (EACT) and Human Cost of Work Assessment Scale (EACHT) - Sinop, MT, Brazil, 2019.

\begin{tabular}{|c|c|c|c|c|c|c|c|c|c|}
\hline \multirow[b]{2}{*}{ Variables } & \multirow[b]{2}{*}{$n(\%)$} & \multicolumn{2}{|c|}{ PHYSICAL } & \multicolumn{2}{|c|}{ PSYCHOLOGICAL } & \multicolumn{2}{|c|}{ SOCIAL RELATIONS } & \multicolumn{2}{|c|}{ ENVIRONMENT } \\
\hline & & $\begin{array}{l}\text { Mean } \\
\text { ranks }\end{array}$ & $p$-value & $\begin{array}{l}\text { Mean } \\
\text { ranks }\end{array}$ & $p$-value & $\begin{array}{l}\text { Mean } \\
\text { ranks }\end{array}$ & $p$-value & $\begin{array}{l}\text { Mean } \\
\text { ranks }\end{array}$ & $p$-value \\
\hline \multicolumn{10}{|c|}{ Work conditions } \\
\hline Satisfactory & $236(78.9)$ & 155.48 & & 154.61 & & 152.85 & & 157.55 & \\
\hline Critical & $61(20.4)$ & 130.14 & 0.095 & 131.17 & 0.143 & 139.28 & 0.518 & 123.80 & $0.008^{(a)}$ \\
\hline Severe & $2(0.7)$ & 108.75 & & 179.75 & & 141.00 & & 58.25 & \\
\hline \multicolumn{10}{|c|}{ Work organization } \\
\hline Satisfactory & $90(30.1)$ & 160.63 & & 153.15 & & 164.51 & & 157.48 & \\
\hline Critical & 195(65.2) & 147.44 & 0.166 & 151.43 & 0.195 & 142.46 & 0.099 & 148.84 & 0.265 \\
\hline Severe & $14(4.7)$ & 117.32 & & 109.82 & & 161.71 & & 118.00 & \\
\hline \multicolumn{10}{|c|}{ Socioprofessional relations } \\
\hline Satisfactory & $228(76.3)$ & 158.35 & & 156.25 & & 160.70 & & 162.25 & \\
\hline Critical & $67(22.4)$ & 127.52 & $0.003^{(b, c)}$ & 132.42 & $0.028^{* *}$ & 117.39 & $0.001^{(c)}$ & 115.06 & $0.001^{(a, b)}$ \\
\hline Severe & $4(1.3)$ & 50.38 & & 88.00 & & 86.38 & & 37.00 & \\
\hline \multicolumn{10}{|l|}{ Physical cost } \\
\hline Satisfactory & $55(18.4)$ & 169.65 & & 173.05 & & 152.10 & & 165.69 & \\
\hline Critical & 191(63.9) & 145.78 & 0.170 & 145.38 & 0.085 & 147.25 & 0.703 & 147.42 & 0.309 \\
\hline Severe & $53(17.7)$ & 144.82 & & 142.73 & & 157.75 & & 143.03 & \\
\hline \multicolumn{10}{|l|}{ Cognitive cost } \\
\hline Satisfactory & $34(11.4)$ & 148.13 & & 144.28 & & 156.37 & & 138.59 & \\
\hline Critical & $164(54.8)$ & 148.40 & 0.897 & 148.57 & 0.800 & 142.41 & 0.215 & 147.81 & 0.484 \\
\hline Severe & $101(33.8)$ & 153.23 & & 154.24 & & 160.17 & & 157.40 & \\
\hline \multicolumn{10}{|l|}{ Affective cost } \\
\hline Satisfactory & $202(67.6)$ & 150.48 & & 145.05 & & 143.86 & & 148.21 & \\
\hline Critical & $86(28.8)$ & 145.78 & 0.578 & 158.26 & 0.283 & 158.95 & 0.081 & 155.56 & 0.736 \\
\hline Severe & $11(3.7)$ & 174.27 & & 176.32 & & 192.82 & & 139.41 & \\
\hline
\end{tabular}

Legend: ** Kruskal-Wallis test (Dunn's post-hoc test $\mathrm{p}<0.05)$ with ${ }^{\text {(a) }}$ 'severe' $\neq$ 'satisfactory'; (b) 'critical' $\neq$ 'satisfactory'; (c) 'critical' $\neq$ 'satisfactory'. Note: $(\mathrm{n}=299)$.

have positively impacted the Physical and Environmental Domains, whereas the Affective Cost has positively impacted the Social Relations Domains of QL, as shown in Table 3.

\section{DISCUSSION}

Concerning the sociodemographic profile of the rural workers of this research, a similarity was observed with the profile of agricultural workers in the United States, according to the American Department of Labor, Employment and Training Administration, which, in a publication about the demographic profile of the agricultural workers, has shown a predominance of men (68\%) with a mean age of 38 , married (57\%), and with children $(55 \%)^{(16)}$.

Concerning the assessment of the Work Context, rural workers were verified to consider the Work Conditions and Socioprofessional Relations as satisfactory. However, Work Organization was considered critical by the study participants, revealing a possibility of these workers falling ill due to a Work Organization characterized by the division of tasks, norms, and rigid controls and intense work rhythm.

Upon assessment of the impact of the Work Context on the QL of workers, the Socioprofessional Relations were verified to have a negative influence over all domains (Physical, Psychological, Social, and Environmental), emerging as a negative predictor for the $\mathrm{QL}$ of the studied workers. The Socioprofessional Relations refer to the intraand intergroup and external collective hierarchical interactions in the context of labor ${ }^{(6)}$. It is thus necessary to account for the inter-relation between the organizational processes as factors which impact health and worker QL, and that, frequently, the approaches to QL at work practiced in the organizations tend to hide these relations and shape worker behavior rather than search for effective solutions to cope with the experienced inter-relational problems ${ }^{(17)}$. 
Table 3 - Final regression model via GAMLSS per overall quality of life and the domains of WHOQOL-bref in rural workers - Sinop, MT, Brazil, 2019.

\begin{tabular}{|c|c|c|c|c|c|}
\hline WHOQOL-Bref Scale & Variables & Estimate & Standard error & Statistics Z & $\mathbf{p}$ \\
\hline \multirow{7}{*}{ Overall quality of life } & Intercept & 82.84 & 3.83 & 21.62 & $<0.001$ \\
\hline & Work conditions & -1.69 & 1.57 & -1.08 & 0.283 \\
\hline & Work organization & 0.57 & 1.52 & 0.38 & 0.706 \\
\hline & Socioprofessional relations & -3.69 & 1.29 & -2.87 & $0.004^{*}$ \\
\hline & Physical cost & 0.91 & 1.03 & 0.89 & 0.377 \\
\hline & Cognitive cost & -0.53 & 1.09 & -0.49 & 0.627 \\
\hline & Affective cost & 0.80 & 1.11 & 0.72 & 0.472 \\
\hline \multirow{7}{*}{ Physical domain } & Intercept & 99.37 & 3.47 & 28.64 & $<0.001$ \\
\hline & Work conditions & -1.98 & 1.16 & -1.70 & 0.089 \\
\hline & Work organization & -0.47 & 1.17 & -0.40 & 0.687 \\
\hline & Socioprofessional relations & -3.39 & 0.97 & -3.48 & $0.001^{*}$ \\
\hline & Physical cost & -0.66 & 0.78 & -0.84 & 0.401 \\
\hline & Cognitive cost & 1.85 & 0.84 & 2.20 & $0.029^{*}$ \\
\hline & Affective cost & -0.41 & 0.85 & -0.48 & 0.632 \\
\hline \multirow{7}{*}{ Psychological domain } & Intercept & 80.61 & 2.48 & 32.48 & $<0.001$ \\
\hline & Work conditions & -0.49 & 1.18 & -0.42 & 0.678 \\
\hline & Work organization & 0.28 & 1.31 & 0.22 & 0.830 \\
\hline & Socioprofessional relations & -2.00 & 0.41 & -4.83 & $<0.001^{*}$ \\
\hline & Physical cost & -1.19 & 0.78 & -1.52 & 0.130 \\
\hline & Cognitive cost & 0.96 & 0.85 & 1.13 & 0.258 \\
\hline & Affective cost & 0.61 & 0.78 & 0.79 & 0.431 \\
\hline \multirow{7}{*}{ Social relations domain } & Intercept & 78.15 & 4.00 & 19.52 & $<0.001$ \\
\hline & Work conditions & -0.36 & 1.45 & -0.25 & 0.802 \\
\hline & Work organization & -0.26 & 1.53 & -0.17 & 0.866 \\
\hline & Socioprofessional relations & -4.80 & 1.22 & -3.94 & $0.000^{*}$ \\
\hline & Physical cost & 0.20 & 1.07 & 0.19 & 0.850 \\
\hline & Cognitive cost & 0.64 & 1.09 & 0.59 & 0.557 \\
\hline & Affective cost & 2.69 & 1.27 & 2.12 & $0.035^{*}$ \\
\hline \multirow{7}{*}{ Environmental domain } & Intercept & 75.75 & 3.82 & 19.83 & $<0.001$ \\
\hline & Work conditions & -2.05 & 1.39 & -1.47 & 0.143 \\
\hline & Work organization & -0.97 & 1.31 & -0.74 & 0.460 \\
\hline & Socioprofessional relations & -5.04 & 1.11 & -4.55 & $<0.001 *$ \\
\hline & Physical cost & -1.33 & 0.96 & -1.39 & 0.166 \\
\hline & Cognitive cost & 3.78 & 1.01 & 3.76 & $<0.001^{*}$ \\
\hline & Affective cost & -0.06 & 1.01 & -0.06 & 0.952 \\
\hline
\end{tabular}

Legend: * Significant variables at $5 \%$ of significance (the same as $95 \%$ confidence).

Note: $(n=299)$.

A study conducted in the state of California, USA, on satisfaction with rural work has shown that workers were "very satisfied" with the nature of agricultural work, their supervisors, and co-workers. The levels of satisfaction were relatively high for internal communication, salaries, and family commitments. The workers were "extremely dissatisfied" with their way to work and "dissatisfied" with work consequences for health. They were "a little dissatisfied" with the additional benefits they were offered, the opportunities of promotion, and contingent rewards ${ }^{(18)}$. In other words, 
the North American agricultural workers have also shown satisfaction with the Socioprofessional Relations.

However, it is necessary to consider that, in rural work, factors such as a reduced possibility of professional growth, a model of production focused on standardization and task fragmentation ${ }^{(19)}$, as well as the difficulties faced due to a Work Organization which is unable to meet the workers' needs may negatively impact the hierarchical relations and relations among peers ${ }^{(20)}$, which may explain the lower QL scores among workers which critically assessed the Socioprofessional Relations. Thus, the elimination of psychosocial stressors, such as extenuating workload, demands for productivity, coping with contradictory instructions, among others present in the environment of rural work, may be beyond the scope of health and agricultural safety professionals. Thus, the need for incorporating stress management and interventions for protection against mental health conditions is emphasized ${ }^{(21)}$.

The negative assessment of Work Organization may be explained by the long working time, disperse work, excessive journeys, diversity, and variation of the performed activities and extenuating working hours ${ }^{(18)}$, factors which are commonly emphasized in the context of Brazilian agricultural production. In the United States and Mexico, the context of production in agricultural work presents characteristics such as more division of labor, investment in workers to increase their productivity, and development of better production techniques ${ }^{(22)}$, aspects also shown in Brazil. Also, "repetitive procedures, imposition of rhythms and rigidity when performing this activity may lead to worker suffering" ${ }^{(8)}$ and impact worker QL.

The assessment of demands regarding work, signaled by the Human Cost of Work, has presented a worrisome panorama, given that a higher prevalence of critical and severe assessments for Physical Cost and Cognitive Cost among the studied rural workers was verified. In this sense, this context is observed to have been demanding a high physical and cognitive cost from them. Considering the Psychodynamics of Work framework, worker exposure to a high human cost may lead to illness on the long term ${ }^{(6)}$.

The presence of a critical assessment of the Physical Cost among rural workers in the soybean context shows the importance of assessing the physical environment to which workers are exposed. The assessment of physical wear and its related peculiarities show important sides of the context in which workers are inserted ${ }^{(23)}$. The characteristics of the activity to which workers are exposed, with enormous physiological effort, may contribute to illness, absence, and work leave, showing the interference of work on worker health ${ }^{(24)}$. An extenuating physical workload may lead to a compromised body system, psychological well-being, socioaffective relations, the perception of labor and work satisfaction ${ }^{(25)}$.

The highest Cognitive Cost may be strictly related to changes in the field, particularly in soybean production, in which the extensive use of technology has the objective of increasing production in the same planted area. This logic requires from rural workers an improvement in the manipulation of high-technology agricultural implements and pesticides, which must be calculated properly to avoid losing the production.

The Green Revolution promoted the implementation of rural technologies both in agriculture and husbandry, aimed at increasing productivity ${ }^{(26)}$ and encouraged rearrangement of rural work to new technologies for production, organization, and productive process management, "a change which implies higher demand from more qualified professionals, with the need of professionals who are able to absorb and adapt modern cultivation techniques and plan agricultural phase management"(27). In the state of Mato Grosso, soybeans present a highly mechanized production, in which planting and harvesting are completely mechanical and controlled via satellite and on-board computer through the system of precision agriculture ${ }^{(28)}$.

Although the workers have assessed the Cognitive Cost as critical, indicating a high mental effort, it has positively impacted the Physical and Environmental Domains. This is a plausible result, given that a higher use of technology leads to smaller use of physical force by the rural workers. Before the modernization of agricultural activities, workers were exposed to a higher physical effort (manual harvest) and more adverse environment (sun exposure and environmental change, such as rain and intense heat). Currently, planting and harvesting are performed through highly technological agricultural machinery, with closed cabins, free from noise, and with air-conditioner, which may have positive effects on this result.

The Affective Cost was considered satisfactory by $67.6 \%$ of the investigated rural workers, having a favorable impact on the assessment of the Social Relations Domain in the multivariate analysis. Through the Psychodynamics of Work theoretical framework ${ }^{(5)}$, this phenomenon can be understood, given that workers, even when faced with work processes which cause suffering, can find pleasure and disposition to face reality through defensive strategies to achieve psychic equilibrium $^{(7,9)}$.

Given the Context and Human Cost of Work by male rural workers in the context of soybean production, a need for a higher insertion of work nursing in this reality is verified, since many services targeted at workers worldwide are offered by occupational health nurses independently or in collaboration with professionals of other disciplines. These services may be of health protection and promotion, but also targeted at reduction of health aggravations and improvement of worker QL ${ }^{(29)}$. In Brazil, the urgency for health teams providing care in rural areas to recognize health problems related to the context of labor affecting this population, with more focus on preventive and health promotion actions, is emphasized ${ }^{(30)}$.

In this context, Nursing, a profession which is more present in Primary Healthcare, requires more investment on professional qualification for providing care to rural populations and on the specific education for qualified care towards male rural workers.

Some limitations of this study should be emphasized; these were related to contacting rural workers since the 
studied sample was mostly comprised of workers of large-sized properties. Reality, mainly concerning Work Conditions, is believed to possibly differ from what this research has verified. In this sense, the conduction of research targeted at small rural properties is recommended. The conduction of this study in the work environment is also a limitation, as this may have intimidated workers, influencing their answers.

Despite these limitations, this study is believed to have as its strongest point the communication with a group of workers which - even if little studied in the literature brings important contributions to the Brazilian economy. Thus, understanding their Work Conditions, giving shape to the vulnerabilities of this context, is highly valuable for the promotion of socioenvironmental policies focused on work relations. From these results, new forms of Organization of Rural Work may be conceived, particularly in the context of soybeans.

Concerning the Nursing care, Rural Worker Health is emphasized to be a prolific professional field, with a possibility that Nursing may contribute, through the framework of Psychodynamics of Work, to mitigate the risks of this labor activity. This study's findings are expected to influence the elaboration, planning, and execution of public policies to reduce the harmful effects of Work Conditions in the context of soybeans, as well as in similar realities.

\section{CONCLUSION}

Regarding Context of Work, rural workers have assessed the Conditions of Work as satisfactory; Work Organization was considered critical and Socioprofessional Relations were satisfactory. Concerning the Human Cost of Work, workers have assessed the Physical and Cognitive Cost as critical and the Affective Cost as satisfactory.

Regarding the repercussions of the Context of Work on the QL of rural workers, the Socioprofessional Relations were verified to negatively impact all domains and the overall QL of these workers. However, the factor Cognitive Cost was shown to positively impact the Physical and Environmental Domains, whereas the Affective Cost has positively impacted the Social Relations Domain of QL.

\section{RESUMO}

Objetivo: Avaliar o contexto de trabalho e analisar suas repercussões na qualidade de vida de trabalhadores rurais do agronegócio da soja. Método: Estudo transversal, com amostra intencional de trabalhadores rurais, realizado entre os meses de outubro e dezembro de 2019, com aplicação dos instrumentos World Health Organization Quality Life-bref e Escalas de Avaliação do Contexto e Custo Humano do Trabalho. Os dados foram analisados por meio de estatística descritiva, bivariada e multivariada. Resultados: Participaram 299 trabalhadores rurais. Os escores das Condições de Trabalho e das Relações Socioprofissionais foram satisfatórios e o da Organização do Trabalho foi crítico. Os escores dos Custos Físico e Cognitivo foram considerados críticos e o do Custo Afetivo, satisfatório. As Relações Socioprofissionais repercutiram negativamente na qualidade de vida geral e nos Domínios Físico e Psicológico, nas Relações Sociais e no Meio Ambiente, enquanto o Custo Cognitivo repercutiu positivamente nos Domínios Físico e no Meio Ambiente e o Custo Afetivo repercutiu positivamente no Domínio das Relações Sociais. Conclusão: Apesar de o Contexto e o Custo Humano do Trabalho indicarem condições adversas, somente as Relações Socioprofissionais exerceram influências negativas na qualidade de vida dos trabalhadores rurais.

\section{DESCRITORES}

Trabalhadores rurais; Condições de Trabalho; Qualidade de vida; Saúde do Trabalhador; Enfermagem do Trabalho.

\section{RESUMEN}

Objetivo: Evaluar el contexto de trabajo y analizar sus repercusiones en la calidad de vida de los trabajadores rurales de la agroindustria de la soja. Método: Estudio transversal con una muestra intencional de trabajadores rurales, realizado entre los meses de octubre y diciembre de 2019, con aplicación de los instrumentos World Health Organization Quality Life-bref y Escalas de Evaluación del Contexto y Costo Humano del Trabajo. Los datos se analizaron mediante estadísticas descriptivas, bivariadas y multivariadas. Resultados: Participaron un total de 299 trabajadores rurales. Las puntuaciones de las Condiciones de Trabajo y las Relaciones Socioprofesionales fueron satisfactorias y la de la Organización del Trabajo fue crítica. Las puntuaciones de los Costos Físico y Cognitivo fueron consideradas críticas y la del Costo Afectivo fue satisfactoria. Las Relaciones Socioprofesionales impactaron negativamente la calidad de vida global y los Dominios Físico y Psicológico, Relaciones Sociales y Entorno, mientras que el Costo Cognitivo impactó positivamente los Dominios Físico y Entorno y el Costo Afectivo impactó positivamente el Dominio de Relaciones Sociales. Conclusión: Aunque el Contexto y el Costo Humano del Trabajo indican condiciones adversas, sólo las Relaciones Socioprofesionales ejercieron influencias negativas en la calidad de vida de los trabajadores rurales.

\section{DESCRIPTORES}

Trabajadores Rurales; Condiciones de Trabajo; Calidad de Vida; Salud Laboral; Enfermería del Trabajo.

\section{REFERENCES}

1. Departamento Intersindical de Estatística e Estudos Socioeconômicos. O mercado de trabalho assalariado rural brasileiro. Estudos Pesq. 2014;(75):1-33.

2. Brasil. Ministério da Agricultura, Pecuária e Abastecimento; Companhia Nacional de Abastecimento. Safra brasileira de grãos. Brasília: Conab; 2020.

3. The Whoqol Group. The World Health Organization Quality of Life assessment (WHOQOL): position paper from the World Health Organization. Soc Sci Med. 1995;41(10):1403-9. https://doi.org/10.1016/0277-9536(95)00112-K

4. Angelim RCM, Figueiredo TR, Correia PP, Bezerra SMMS, Baptista RS, Abrão FMS. Avaliação da qualidade de vida por meio do Whoqol: análise bibliométrica da produção de enfermagem. Rev Baiana Enferm. 2015;29(4):400-10. http://dx.doi.org/10.18471/rbe.v29i4.11857 
5. Dejours C. Psicodinâmica do trabalho: contribuições da escola dejouriana à análise da relação prazer, sofrimento e trabalho. São Paulo: Atlas, 1994.

6. Mendes AM, Ferreira MC, Cruz RM. Inventário sobre Trabalho e Riscos de Adoecimento (ITRA): instrumento auxiliar de diagnóstico de indicadores críticos no trabalho. In: Mendes AM, organizador. Psicodinâmica do trabalho: teoria, método e pesquisas. São Paulo: Casa do Psicólogo; 2007. p.111-26.

7. Aciole GG, Pedro MJ. Sobre a saúde de quem trabalha em saúde: revendo afinidades entre a psicodinâmica do trabalho e a saúde coletiva. Saúde Debate. 2019;43:194-206. https://doi.org/10.1590/0103-1104201912015

8. Silva RM, Limas BT, Pereira LS. Contexto de trabalho e custo humano no trabalho: um estudo com trabalhadores portuários de transporte. Barbaroi. 2016;46:98-118. http://dx.doi.org/10.17058/barbaroi.v0i46.6410

9. Santos OOA, Machado ACA, Facas EP. Psicodinâmica do trabalho e atividade pastoral. Trabalho (En)Cena. 2018;3(3):115-38. https://10.20873/2526-1487V3N3P115

10. Siqueira DF, Moura RM, Laurentino GEC, Silva GPF, Soares LDA, Lima BRDA. Qualidade de vida de trabalhadores rurais e agrotóxicos: uma revisão sistemática. Rev Bras Ciênc Saúde. 2012;16(2):259-66. https://doi.org/10.4034/RBCS.2012.16.02.22

11. Cezar-Vaz MR, Bonow CA, Mello MCVA, Silva MRS. Abordagem socioambiental na enfermagem: focalizando o trabalho rural e uso de agrotóxicos. Rev Bras Enferm. 2016;69(6):1179-87. http://dx.doi.org/10.1590/0034-7167-2016-0364

12. Oliveira AR, Sousa YG, Silva DM, Alves JP, Diniz IVA, Medeiros SM, et al. A Atenção Primária à Saúde no contexto rural: visão de enfermeiros. Rev Gaúcha Enferm. 2020;41:e20190328. https://doi.org/10.1590/1983-1447.2020.20190328

13. Instituto Brasileiro de Geografia e Estatística. Censo Agropecuário, 2017 [Internet]. Rio de Janeiro: IBGE; 2017 [cited 2020 jun. 14 ]. Available from: https://censos.ibge.gov.br/agro/2017

14. The Whoqol Group. Development of the World Health Organization WHOQOL-BREF quality of life assessment. Psychol Med. 1998;28(3):551-8. https://doi.org/10.1017/S0033291798006667

15. Stasinopoulos DM, Rigby RA. Generalized Additive Models for Location Scale and Shape (GAMLSS) in R. J Statistical Software [Internet]. 2007 [cited 2020 Aug 27];23(7):1-10. Available from: https://www.jstatsoft.org/article/view/v023i07

16. Hernandez T, Gabbard S. Findings from the National Agricultural Workers Survey (NAWS) 2015-2016: a demographic and employment profile of United States farmworkers [Internet]. Washington: Department of Labor; 2019 [cited 2020 Aug 27]. Available from: http://hdl. voced.edu.au/10707/504095

17. Ferreira MC. A ergonomia da atividade pode promover a qualidade de vida no trabalho? Reflexões de natureza metodológica. Rev Psicol Org Trabalho [Internet]. 2011 [cited 2020 ago. 27];11(1):8-20. Available from: https://periodicos.ufsc.br/index.php/rpot/article/view/22243

18. Hobbs M, Klachky E, Cooper LM. Job satisfaction assessments of agricultural workers help employers improve the work environment and reduce turnover. Calif Agric. 2020;74(1):30-9. https://doi.org/10.3733/ca.2020a0002

19. Charlton D. Development of agricultural supply through structural changes in labor inputs. New York: UC Davis; 2019.

20. Campos JF, David HSL. Work context assessment in intensive therapy units from the perspective of work psychodynamics. Rev Esc Enferm USP. 2011;45(2):363-8. http://dx.doi.org/10.1590/S0080-62342011000200009

21. Antloga CS, Maia M, Cunha KR, Peixoto J. Contexto de trabalho e custo humano no trabalho em um órgão do poder judiciário brasileiro. Ciênc Saúde Coletiva. 2014;19(12):4787-96. https://doi.org/10.1590/1413-812320141912.22252013

22. Rudolphi J. Diversity of mental health issues in agriculture. J Agromed. 2019;25(1):1. https://doi.org/10.1080/1059924X.2020.1694821

23. Hoffmann C, Traverso LD, Zanini RR. Contexto de trabalho das pessoas com deficiência no Serviço Público Federal: contribuições do inventário sobre trabalho e riscos de adoecimento. Gest Prod. 2014;21(4):707-18. https://doi.org/10.1590/0104-530X379

24. Guimarães MC. Custo humano de trabalho e estratégias de mediação em trabalhadores rurais In: Mendes AM, organizador. Psicodinâmica e clínica do trabalho: temas, interfaces e casos brasileiros. Curitiba: Juruá; 2012.

25. Silva RM, Tiepo MVS. Condições de trabalho, custo humano e dano físico: um estudo com estivadores de um terminal portuário. Barbaroi. 2016;48:135-52. http://dx.doi.org/10.17058/barbaroi.v0i48.9589

26. Koglin AP, Bezzi ML. A modernização da agricultura e os impactos na organização socioespacial do município de Toropi-RS. Soc Território. 2019;31(2):156-76. https://doi.org/10.21680/2177-8396.2019v31n2ID18305

27. Mesquita FC, Furtado AT. Expansão da agroindústria canavieira e qualificação da mão-de-obra em Goiás (2006-2013). Soc Nat. 2016;28(1):67-81. https://doi.org/10.1590/1982-451320160105

28. Soares HV. O trabalho na cadeia da soja no centro-oeste brasileiro: um debate sobre emprego, renda e condições de trabalho na agricultura capitalista contemporânea. Tempos Históricos. 2019;23(1):602-28.

29. Rogers B, Kono K, Marziale MHP, Peurala M, Radford J, Staun J. International survey of occupational health nurses' roles in multidisciplinary teamwork in occupational health services. Workplace Health Saf. 2014;62(7):274-81. https://doi.org/10.1177/216507991406200702

30. Ferraz L, Trindade LL, Bevilaqua E, Santer J. As demandas do homem rural: informações para a assistência nos serviços de saúde da atenção básica. Rev Min Enferm. 2013;17(2):349-55. http://www.dx.doi.org/10.5935/1415-2762.20130026 